\title{
Perceptions of dental students towards online education during the COVID-19 pandemic
}

\section{Purpose}

This study evaluated the usage habits, attitudes, and perceptions of undergraduate dental students toward distance (online) learning and identified variables related to those attitudes.

\section{Materials and Methods}

The study included 1,605 undergraduate dental students who participated voluntarily. The data collection tool consisted of a distance learning attitude scale, a questionnaire on personal information, and open-ended questions. The perceptions of dental students to distance education according to the year and type of dental school they attended were evaluated.

\section{Results}

Most students expressed that distance learning in dental courses was not as effective as traditional face-to-face education (59.1\%, $n=949)$. While students studying at state universities had a more negative view of distance education, the satisfaction scores of the first-year students were found to be significantly lower than the other students $(p<0.05)$.

\section{Conclusion}

Dental students were generally unhappy with the interruption of traditional education caused by COVID-19 and having to continue their education online. However, under the circumstances, they saw it as an advantage allowing them to continue their education and avoid a complete suspension.

Keywords: COVID-19, survey, distance education, online education, undergraduate student

\section{Introduction}

Distance education is a teaching method transmitted via certain centers and depends on individuals' self-learning goals, educational content, and tools specially designed for learners in myriad environments. Physically, it is a planned form of teaching in which students do not need to be in a specific place; students and teachers keep in touch synchronously or asynchronously via communication technologies with the help of the internet environment (1). Synchronic or asynchronous technologies for online education include websites, podcasts, mobile applications, blogs, discussion boards, internet forums, interactive online tutorials, video conference technology, and virtual learning management systems (2). In distance education, each student learns at their own pace with quick and easy access to the materials. It affords the opportunity to acquire an education and eliminates many expenses, such as transportation and accommodations at a learning institution (1). Another advantage of distance learning is that it can provide students with "easier and more effective access to a wider variety and greater quantity of information" (3). The jus-

\author{
Ayca Sarıalioglu Gungor ${ }^{1} \mathbb{D}$, \\ Yesim Sesen Uslu² ${ }^{2}$, \\ Nazmiye Donmez ${ }^{1}$ (D)
}

ORCID IDs of the authors: A.S.G. 0000-0002-8779-2949; Y.Ş.U. 0000-0001-9601-7410; N.D. 0000-0002-5101-6155

'Department of Restorative Dentistry, Faculty of Dentistry, Bezmialem Vakif University, Istanbul, Turkey

2Department of Restorative Dentistry, Faculty of Dentistry, Istanbul Okan University, Istanbul, Turkey Corresponding Author: Ayca Sarıalioglu Gungor E-mail: aycagungor83@hotmail.com Received: 27 January 2021 Revised: 7 March 2021 Accepted: 24 March 2021 
tification presented by Mattheos et al. (4) that information technologies (e-learning, distance learning, simulations, computer-based assessment) are compatible with dental education is that dental technology incorporates hardware and software applications. Currently, information technologies are being used in patient management software, digital $X$-ray, and so forth in dental practice (5).

Generation $Z$ is classified as the people who were born in the mid-1990s and growing up in the early 2000s. They are mainly characterized by their addiction to computers and other technologies in general. Today's dental school students, part of the $\mathrm{Z}$ generation, have been growing up with the Internet, cell phones, laptops, iPads, tablets, and other electronic devices, which became part of their daily lives (6). Online learning is the education they expect to receive, but this does not mean that they are expected to receive it through mobile devices and distance education (7). It is important to understand their perspectives, attitudes, and opinions on distance education.

When the World Health Organization (WHO) declaring COVID-19 as a pandemic in March 2020, the situation was carefully monitored in our country. In Turkey, the first COVID-19 case was identified on March 11, 2020; consequently, primary, secondary, and higher education were suspended on March 16, 2020. Turkey's Council of Higher Education (CoHE) announced on March 23, 2020, that online education would be at the forefront of education due to the pandemic. This extraordinary experience led individuals unable to take advantage of the unexpected upheaval in the education system to seek alternative forms of education. Many teachers and students had to adapt to this system, called the "education system of the future," which they had not experienced before.

As far as we know, while there are many studies in the literature on distance education, there is a shortage of information about the effectiveness of distance education in dentistry. Therefore, this cross-sectional study aimed to evaluate the effectiveness of distance education from dental students' perspectives to emphasize the areas of weaknesses and strengths within the dental schools of Turkey. It was presumed that this information might be helpful to advance distance (online) education for undergraduates across the whole country. The null hypothesis was that online distance education is perceived as effective as the traditional methods of learning in dental schools.

\section{Materials and Methods}

\section{Ethical statement}

This project has been reviewed and approved by the Ethical Committee of Bezmialem Vakif University (06/108) on May 5, 2020.

\section{Sample size estimation and post-hoc power}

The minimum number of participants required was determined by an a priori power analysis using the software package, GPower 3.1. In order to detect an effect size of Cohen's $\mathrm{d}=0.5$ with $95 \%$ power (alpha $=0.05$, two-tailed), GPower suggests we would need 210 participants in an independent samples t-test. However, 1,605 students who answered the web-based survey completely during the survey application period were included to increase the reliability of the findings. The post hoc power analysis revealed the statistical power for this study was 1.00 (\%100).

\section{Study population}

Currently, there are 65 dental schools at 13 private and 52 state universities in Turkey. However, at the time of the survey, only 33 dental schools continued their learning activities with distance education. An invitation was sent to the associate deans for student affairs of the dental schools. Of the 33 dental schools, 13 (8 state universities, 5 foundation universities) agreed to participate in the survey. In Turkey, the dental education curriculum starts with theoretical education and continues with a clinical program in the third year's spring semester until graduation. As determined by the CoHE, practical classroom instruction was suspended, and the recommendation to teach theoretical lessons using digital platforms in the format of distance learning was promptly followed by dental schools during the spring semester. The survey was launched at the time we experienced the first peak period of the pandemic in Turkey. Undergraduate students in dental schools had completed their theoretical courses with distance (online) education activities during the spring semester. Between May 10 and 20, 2020, questionnaires were distributed to all first, second, third, fourth-, and fifth-year undergraduate students in dental schools who had access to their dental theoretical training from home.

\section{Study design and data collection}

An observational, cross-sectional survey design was used to collect information at a given time (8). The data collection tool consisted of three parts: a questionnaire on students' information, a distance education attitude scale, and open-ended questions. Personal information questions were prepared by the researchers based on previous research in the literature and contained 16 questions regarding the respondents' demographic information (gender, type of university, and current year) and mobile technology usage habits (availability of electronic devices, time spent using the internet, etc.) in general $(7,9,10)$.

\section{Distance education attitude scale}

This scale was developed by Çelik (11) as a five-point, Likert-type scoring instrument consisting of 21 items. The higher the score, the more positive the respondent's attitude is toward distance education. Factor analysis was applied to determine the sub-dimensions of the "attitude scale" within the scope of the Validity-Reliability. Cronbach's alpha coefficients were calculated within the scope of reliability analysis of the scale questions. The statistical significance level (a) was taken as 5\% in calculations. Cronbach's Alpha value for "attitude scale questions" was found to be 0.881 (88.1\%) (11). Accordingly, the Cronbach's Alpha value of these scale questions exceeding $75 \%$ indicates that the reliability of these questions (items) is high. The five optional responses 
for each question include: 5 = strongly agree, $4=$ agree, $3=$ undecided, 2 = disagree, and 1 = strongly disagree.

\section{Opinions of distance education}

This part of the questionnaire consists of three open-ended questions that the researchers of this study generated. While choosing a response was not obligatory, the aim was to gather the students' general views about distance learning (What are the positive aspects of distance education? What are the negative aspects of distance education? What are your suggestions for improvement of distance education?)

Respondents voluntarily consented to take part in the questionnaire and were assured that their answers would be recorded and stored anonymously. They were provided a standardized informed-consent document defining the aim of the study, and the questions were transferred to Google Forms (Google Inc., Mountain View, CA, USA). A web link to the questionnaire was sent by e-mail to full-time lecturers at 23 dental schools to act as contacts, and announcements were disseminated through student communication groups, especially via WhatsApp (WhatsApp Inc., Mountain View, CA, USA) and via student notice boards located in the faculty. The contact people distributed the web link to students willing to participate. A consent form was on the first page of the online questionnaire, which provided prospective participants more detail about the study and obtained their consent to participate. Data collected were stored in a secure database only accessible to the researchers. The data collection process lasted for 10 days. In order to increase participation in the study, announcements were repeated several times during the data collection period. Incomplete questionnaires were excluded to preserve the accuracy of the analysis.

\section{Statistical analysis}

Statistical analyzes were performed using Statistical Package for the Social Sciences (SPSS) 22.0 (IBM Corp., Armonk, NY, USA). While continuous variables were presented as median, categorical variables were described in frequencies and percentages. The Shapiro-Wilk normality test was used to determine the normal distribution; as the data were not normally distributed, minus the descriptive statistical methods (mean, standard deviation, frequency), the Kruskal-Wallis test was conducted to compare the parameters between the year of school, and Dunn's test was used to determine the group that caused the difference. The Mann-Whitney $U$ test was used for comparisons between state and private universities. A value of $p<0.05$ was considered statistically significant. In order to handle any missing data, the direct deletion method was used. All surveys with invalid data were discarded from further analysis, and statistical analysis was conducted on the basis of a complete dataset.

\section{Results}

\section{Personal information}

The study was conducted with the participation of 1,605 dental students. The demographic data showed a gender distribution of 1,048 females (65.3\%) and 557 males (34.7\%). Of the participants, $62.5 \%(n=1,003)$ were studying at state universities and $37.5 \%(n=602)$ at private universities; $16.8 \%$ ( $n=269)$ were in their first year, $21.6 \%(n=346)$ were in their second, $27.4 \%(n=440)$ were in their third, $20.8 \%(n=$ $334)$ were in their fourth, and $13.5 \%(n=216)$ were in their fifth year. The distribution of demographic characteristics of the students is shown in Table 1.

\section{Distance education attitude scale}

Table 2 shows the distribution of students' answers on the distance education attitude scale. Unsurprisingly, the vast majority prefer face-to-face learning over online distance education when the technological conditions at home are at a level adequate to meet distance education standards. The responses of undergraduate dental students on the distance education attitude scale in relation to the type of dental school attended are shown in Figure 1. Statistically significant differences were found between state and private universities on questions $17,23,24,25,26,27,29,30,31,32$, 33,36 , and $37(p<0.05)$.

The responses of undergraduate dental students on the distance education attitude scale according to the year of the dental school are shown in Table 3. There were statistically significant differences in all questions except questions $19,22,30$, and 31 ( $p<0.05)$.

\section{Opinions of distance education}

Students were asked to specify the positive and negative aspects of distance education and any suggestions for improvement of the system. Table 4 shows representative comments given. Suggestions for improving distance education can be summarized as follows: use videos or live demonstrations instead of PowerPoint slides to present information in a more understandable way; make the lectures interactive and synchronous; limit the duration of the lectures to 30 minutes; and provide training on the system used by the lecturers (each demonstrating a standard lecture).

\section{Discussion}

This investigation revealed a negative attitude toward online education among different dental school students during the COVID-19 pandemic in Turkey. According to the results of our study, our null hypothesis was rejected. While before the pandemic, most students $(67.2 \%, n=1,079)$ spent 1-3 hours daily on the internet, this period increased to 4-6

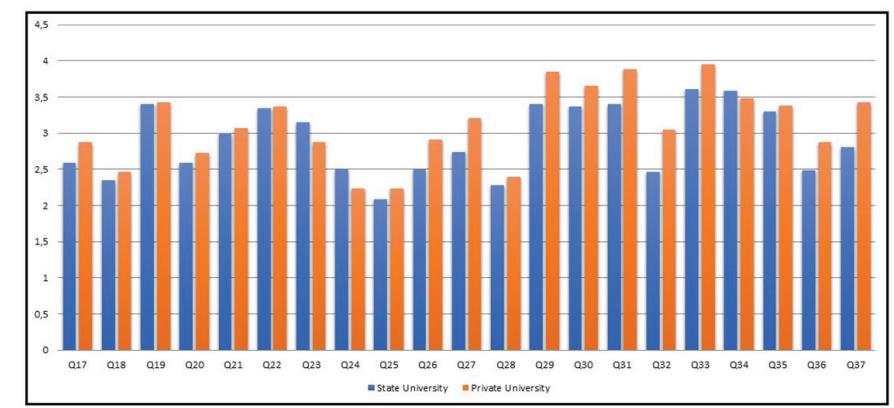

Figure 1. Responses of undergraduate dental students to distance education attitude scale in relation to the type of dental school attended (Mann Whitney U Test, ${ }^{*} p<0.05$ ). 
Table 1. Personal information of dental students.

\begin{tabular}{|c|c|c|c|}
\hline & & $\mathbf{n}$ & $\%$ \\
\hline \multirow{2}{*}{ Gender (Q1) } & Female & 1048 & 65.3 \\
\hline & Male & 557 & 34.7 \\
\hline \multirow{2}{*}{ University (Q2) } & State university & 1003 & 62.5 \\
\hline & Private university & 602 & 37.5 \\
\hline \multirow{6}{*}{ Year of the school (Q3) } & 1st year & 269 & 16.8 \\
\hline & 2nd year & 346 & 21.6 \\
\hline & 3rd year & 440 & 27.4 \\
\hline & 4th year & 334 & 20.8 \\
\hline & 5 th year & 216 & 13.5 \\
\hline & Total & 1605 & 100 \\
\hline \multirow{3}{*}{$\begin{array}{l}\text { Connection to online } \\
\text { courses (Q4) }\end{array}$} & Mobile phone & 510 & 31.8 \\
\hline & $\begin{array}{l}\text { Tablet computer/ } \\
\text { Ipad }\end{array}$ & 329 & 20.5 \\
\hline & Laptop & 766 & 47.7 \\
\hline \multirow{4}{*}{$\begin{array}{l}\text { Internet speed at home } \\
\text { (Q5) }\end{array}$} & 1-4 Mbps & 196 & 12.2 \\
\hline & 5-8 Mbps & 361 & 22.5 \\
\hline & 9-16 Mbps & 544 & 33.9 \\
\hline & $16+\mathrm{Mbps}$ & 504 & 31.4 \\
\hline \multirow{6}{*}{$\begin{array}{l}\text { Number of computers } \\
\text { at home (Q6) }\end{array}$} & None & 9 & 0.6 \\
\hline & 1 & 830 & 51.7 \\
\hline & 2 & 479 & 29.8 \\
\hline & 3 & 222 & 13.8 \\
\hline & 4 & 43 & 2.7 \\
\hline & 5 or more & 22 & 1.4 \\
\hline \multirow{2}{*}{$\begin{array}{l}\text { Do you have a tablet } \\
\text { computer at home? } \\
\text { (Q7) }\end{array}$} & Yes & 715 & 44.5 \\
\hline & No & 890 & 55.5 \\
\hline \multirow{2}{*}{$\begin{array}{l}\text { Do you have your own } \\
\text { study room? (Q8) }\end{array}$} & Yes & 1197 & 74.6 \\
\hline & No & 408 & 25.4 \\
\hline \multirow{2}{*}{$\begin{array}{l}\text { Does your mobile } \\
\text { phone have an internet } \\
\text { package? (Q9) }\end{array}$} & Yes & 1497 & 93.3 \\
\hline & No & 108 & 6.7 \\
\hline \multirow{4}{*}{$\begin{array}{l}\text { Internet package limit } \\
\text { of mobile phone (GB) } \\
\text { (Q10) }\end{array}$} & $2 \mathrm{~GB}$ & 177 & 11 \\
\hline & $4 \mathrm{~GB}$ & 294 & 18.3 \\
\hline & $6 \mathrm{~GB}$ & 400 & 24.9 \\
\hline & $10+\mathrm{GB}$ & 734 & 45.8 \\
\hline \multirow{5}{*}{$\begin{array}{l}\text { Nowadays, how many } \\
\text { hours a day do you } \\
\text { spend time on the } \\
\text { screen? (Q11) }\end{array}$} & None & 20 & 1.2 \\
\hline & $1-3$ & 204 & 12.7 \\
\hline & $4-6$ & 666 & 41.5 \\
\hline & $7-10$ & 539 & 33.6 \\
\hline & More than 10 hours & 176 & 11 \\
\hline \multirow{5}{*}{$\begin{array}{l}\text { Before this period, how } \\
\text { many hours a day did } \\
\text { you spend time on the } \\
\text { screen? (Q12) }\end{array}$} & None & 148 & 9.2 \\
\hline & $1-3$ & 1079 & 67.2 \\
\hline & $4-6$ & 320 & 19.9 \\
\hline & 7-10 & 39 & 2.4 \\
\hline & More than 10 hours & 19 & 1.2 \\
\hline
\end{tabular}

Table 1. Continue.

\begin{tabular}{|c|c|c|c|}
\hline & & $\mathbf{n}$ & $\%$ \\
\hline \multirow{8}{*}{$\begin{array}{l}\text { Which program does } \\
\text { your university use } \\
\text { for online (distance) } \\
\text { education? (Q13) }\end{array}$} & Zoom & 77 & 4.8 \\
\hline & Perculus & 179 & 11.2 \\
\hline & Adobe Connect & 539 & 33.6 \\
\hline & Google Meet & 147 & 9.2 \\
\hline & Blackboard Learn & 176 & 11 \\
\hline & Microsoft Teams & 270 & 16.8 \\
\hline & No online course & 66 & 4.1 \\
\hline & Other & 151 & 9.4 \\
\hline \multirow{5}{*}{$\begin{array}{l}\text { How many minutes } \\
\text { should online lessons } \\
\text { be? (Q14) }\end{array}$} & $20-30$ & 539 & 33.6 \\
\hline & $30-40$ & 622 & 38.8 \\
\hline & $40-50$ & 305 & 19 \\
\hline & $50-60$ & 113 & 7 \\
\hline & More than 1 hour & 26 & 1.6 \\
\hline \multirow{10}{*}{$\begin{array}{l}\text { Scoring of the tool used } \\
\text { to follow online lessons } \\
\text { (Q15) }\end{array}$} & 1 & 127 & 7.9 \\
\hline & 2 & 76 & 4.7 \\
\hline & 3 & 92 & 5.7 \\
\hline & 4 & 118 & 7.4 \\
\hline & 5 & 196 & 12.2 \\
\hline & 6 & 189 & 11.8 \\
\hline & 7 & 308 & 19.2 \\
\hline & 8 & 245 & 15.3 \\
\hline & 9 & 105 & 6.5 \\
\hline & 10 & 149 & 9.3 \\
\hline \multirow{2}{*}{$\begin{array}{l}\text { The suitability of the } \\
\text { environment where the } \\
\text { lectures are listened } \\
\text { and studied for distance } \\
\text { education (Q16) }\end{array}$} & Not suitable & 187 & 11.6 \\
\hline & Suitable & 1418 & 88.4 \\
\hline
\end{tabular}

hours (41.5\%, $\mathrm{n}=666)$ during the pandemic. Similarly, a study conducted in Wuhan showed that people spent excessive time on social media during the pandemic (12). The fact that individuals stay home due to social isolation increased internet usage. In this period, more time than expected was spent online; individuals began experiencing excessive anxiety (uneasiness, anger, aggression, etc.) when they were not using the Internet. After school closures, the transfer of education to digital media and confining social life to the home have greatly increased the use of the internet and social media. Clearly, the use of smart devices increased compared to the pre-pandemic period.

Given the rapid spread of COVID-19 and the increase in countries imposing movement restrictions, spending more time in our daily lives at home requires more data use for work and entertainment. This has had a significant impact on the telecom industry. Although there are risks of encountering internet connection problems, there has been an increasing interest in distance education and teleconferencing applications. The demand for software and social media platforms, such as Google Hangouts (Google Inc., Mountain View, CA, USA), WhatsApp video calls, Zoom (Zoom Video Communications, Inc., San Jose, (A, USA), and Microsoft 
Table 2. Distribution of responses to distance education attitude scale.

\begin{tabular}{|c|c|c|c|c|c|}
\hline & Strongly disagree & Disagree & Undecided & Agree & Strongly agree \\
\hline $\begin{array}{l}\text { I think distance education is a good } \\
\text { education model (Q17) }\end{array}$ & $443(\% 27.6)$ & $294(\% 18.3)$ & $372(\% 23.2)$ & $302(\% 18.8)$ & $194(\% 12.1)$ \\
\hline $\begin{array}{l}\text { I find distance education more efficient than } \\
\text { face-to-face learning (Q18) }\end{array}$ & $650(\% 40.5)$ & $299(\% 18.6)$ & $250(\% 15.6)$ & $190(\% 11.8)$ & $216(\% 13.5)$ \\
\hline $\begin{array}{l}\text { I believe that distance education is only an } \\
\text { education study that cannot be done in class } \\
\text { and / or to support it (Q19) }\end{array}$ & $224(\% 14)$ & $232(\% 14.5)$ & $282(\% 17.6)$ & $398(\% 24.8)$ & $469(\% 29.2)$ \\
\hline $\begin{array}{l}\text { Distance education is the education model } \\
\text { of the future }(\mathrm{Q} 20)\end{array}$ & $560(\% 34.9)$ & $256(\% 16)$ & $263(\% 16.4)$ & $252(\% 15.7)$ & $274(\% 17.1)$ \\
\hline $\begin{array}{l}\text { In distance education, students learn more } \\
\text { independently (compared to face-to-face } \\
\text { learning) (Q21) }\end{array}$ & $351(\% 21.9)$ & $218(\% 13.6)$ & $387(\% 24.1)$ & $346(\% 21.6)$ & 303 (\%18.9) \\
\hline
\end{tabular}

I prefer online (simultaneous) distance education compared to offline distance education (Q22)

\begin{tabular}{|c|c|c|c|c|c|}
\hline $\begin{array}{l}\text { I don't think I learned anything through } \\
\text { distance education (Q23) }\end{array}$ & $351(\% 21.9)$ & $210(\% 13.1)$ & $431(\% 26.9)$ & $232(\% 14.5)$ & $381(\% 23.7)$ \\
\hline I find distance education unnecessary (Q24) & $577(\% 36)$ & $353(\% 22)$ & $342(\% 21.3)$ & $119(\% 7.4)$ & $214(\% 13.3)$ \\
\hline $\begin{array}{l}\text { I work harder in the distance education } \\
\text { period than before (Q25) }\end{array}$ & $733(\% 45.7)$ & $317(\% 19.8)$ & $290(\% 18.1)$ & $130(\% 8.1)$ & $135(\% 8.4)$ \\
\hline $\begin{array}{l}\text { I can focus on distance education courses } \\
\text { (Q26) }\end{array}$ & $449(\% 28)$ & $342(\% 21.3)$ & $333(\% 20.7)$ & $278(\% 17.3)$ & $203(\% 12.6)$ \\
\hline $\begin{array}{l}\text { I am satisfied with distance education } \\
\text { courses (Q27) }\end{array}$ & $356(\% 22.2)$ & $261(\% 16.3)$ & $383(\% 23.9)$ & $372(\% 23.2)$ & $233(\% 14.5)$ \\
\hline $\begin{array}{l}\text { I prefer distance education to face-to-face } \\
\text { learning (Q28) }\end{array}$ & $731(\% 45.5)$ & $263(\% 16.4)$ & $209(\% 13)$ & $166(\% 10.3)$ & $236(\% 14.7)$ \\
\hline $\begin{array}{l}\text { I have the necessary knowledge } \\
\text { infrastructure to follow distance education } \\
\text { courses (Q29) }\end{array}$ & $144(\% 9)$ & $168(\% 10.5)$ & $358(\% 22.3)$ & $494(\% 30.8)$ & $441(\% 27.5)$ \\
\hline $\begin{array}{l}\text { Whether or not there is an infrastructure } \\
\text { for distance education will be an effective } \\
\text { criterion in future school preferences (Q30) }\end{array}$ & $178(\% 11.1)$ & $173(\% 10.8)$ & $372(\% 23.2)$ & $473(\% 29.5)$ & $409(\% 25.5)$ \\
\hline $\begin{array}{l}\text { Our technological conditions at home are } \\
\text { sufficient for conducting distance education } \\
\text { activities (Q31) }\end{array}$ & $175(\% 10.9)$ & $188(\% 11.7)$ & $293(\% 18.3)$ & $425(\% 26.5)$ & $524(\% 32.6)$ \\
\hline $\begin{array}{l}\text { My university provides all the support we } \\
\text { need during the distance education process } \\
\text { (Q32) }\end{array}$ & $394(\% 24.5)$ & $339(\% 21.1)$ & $426(\% 26.5)$ & $273(\% 17)$ & $173(\% 10.8)$ \\
\hline $\begin{array}{l}\text { I think it is an important advantage that I } \\
\text { can receive courses on the computer when } \\
\text { necessary (Q33) }\end{array}$ & $121(\% 7.5)$ & $144(\% 9)$ & 327 (\%20.4) & $461(\% 28.7)$ & $552(\% 34.4)$ \\
\hline $\begin{array}{l}\text { I think a lot is expected from students in the } \\
\text { distance education process (Q34) }\end{array}$ & $118(\% 7.4)$ & $221(\% 13.8)$ & $438(\% 27.3)$ & $335(\% 20.9)$ & $493(\% 30.7)$ \\
\hline $\begin{array}{l}\text { The success of distance education models } \\
\text { depends on the teacher (Q35) }\end{array}$ & $107(\% 6.7)$ & $226(\% 14.1)$ & $562(\% 35)$ & $455(\% 28.3)$ & $255(\% 15.9)$ \\
\hline $\begin{array}{l}\text { Instructors can motivate me for distance } \\
\text { education courses (Q36) }\end{array}$ & $375(\% 23.4)$ & $352(\% 21.9)$ & $484(\% 30.2)$ & 271 (\%16.9) & $123(\% 7.7)$ \\
\hline $\begin{array}{l}\text { I think the instructors successfully run the } \\
\text { distance education process (Q37) }\end{array}$ & 241 (\%15) & $266(\% 16.6)$ & $481(\% 30)$ & $423(\% 26.4)$ & $194(\% 12.1)$ \\
\hline
\end{tabular}

Teams (Microsoft Corporation, Redmond, Washington), has increased accordingly (13-19). Distance education as much as possible continued uninterruptedly in universities in which face-to-face education was interrupted by the pan- demic. The top three (and most frequently used) internet communication platforms by dental schools for online education in Turkey were Adobe Connect (Adobe Inc., CA, USA; $33.6 \%)$, Microsoft Teams (16.8\%), and Perculus (Advancity, 
Table 3. Responses to distance education attitude scale according to the year of the school. Kruskal Wallis Test * $p<0.05$.

\begin{tabular}{|c|c|c|c|c|c|c|}
\hline & 1 st year & 2nd year & 3rd year & 4th year & 5th year & \\
\hline & $\begin{array}{c}\text { Mean } \pm S D \\
\text { (median) }\end{array}$ & $\begin{array}{r}\text { Mean } \pm S D \\
\text { (median) }\end{array}$ & $\begin{array}{c}\text { Mean } \pm \text { SD } \\
\text { (median) }\end{array}$ & $\begin{array}{c}\text { Mean } \pm \text { SD } \\
\text { (median) }\end{array}$ & $\begin{array}{c}\text { Mean } \pm \text { SD } \\
\text { (median) }\end{array}$ & $\mathbf{p}$ \\
\hline Q17 & $2.08 \pm 1.26(2)$ & $2.55 \pm 1.31(2)$ & $2.85 \pm 1.38(3)$ & $2.93 \pm 1.3(3)$ & $3 \pm 1.4(3)$ & $0,000^{*}$ \\
\hline Q18 & $1.84 \pm 1.25(1)$ & $2.25 \pm 1.42(2)$ & $2.52 \pm 1.48(2)$ & $2.66 \pm 1.45(2.5)$ & $2.62 \pm 1.45(2)$ & $0,000^{*}$ \\
\hline Q19 & $3.49 \pm 1.41(4)$ & $3.51 \pm 1.4(4)$ & $3.4 \pm 1.4(4)$ & $3.24 \pm 1.39$ (3) & $3.42 \pm 1.35(4)$ & 0.069 \\
\hline Q20 & $2.23 \pm 1.43(2)$ & $2.41 \pm 1.43(2)$ & $2.78 \pm 1.52(3)$ & $2.91 \pm 1.51(3)$ & $2.83 \pm 1.53(3)$ & $0.000 *$ \\
\hline Q21 & $2.79 \pm 1.46(3)$ & $2.9 \pm 1.41(3)$ & $3.09 \pm 1.37(3)$ & $3.24 \pm 1.38(3)$ & $3.02 \pm 1.42(3)$ & $0.001^{*}$ \\
\hline Q22 & $3.2 \pm 1.53(3)$ & $3.43 \pm 1.47(4)$ & $3.35 \pm 1.47(4)$ & $3.32 \pm 1.44$ (3) & $3.47 \pm 1.42(4)$ & 0.276 \\
\hline Q23 & $3.51 \pm 1.39(4)$ & $3.19 \pm 1.44$ (3) & $2.89 \pm 1.45(3)$ & $2.88 \pm 1.46(3)$ & $2.86 \pm 1.36(3)$ & $0.000^{*}$ \\
\hline Q24 & $2.84 \pm 1.49$ (3) & $2.54 \pm 1.4(2)$ & $2.26 \pm 1.32(2)$ & $2.2 \pm 1.3(2)$ & $2.24 \pm 1.32(2)$ & $0.000 *$ \\
\hline Q25 & $1.81 \pm 1.22(1)$ & $2.13 \pm 1.35(2)$ & $2.17 \pm 1.31(2)$ & $2.3 \pm 1.31(2)$ & $2.24 \pm 1.26(2)$ & $0.000 *$ \\
\hline Q26 & $2.18 \pm 1.3(2)$ & $2.53 \pm 1.36(2)$ & $2.71 \pm 1.4(3)$ & $2.87 \pm 1.33$ (3) & $3 \pm 1.35(3)$ & $0.000 *$ \\
\hline Q27 & $2.26 \pm 1.25(2)$ & $2.8 \pm 1.34(3)$ & $3.05 \pm 1.39$ (3) & $3.22 \pm 1.28(3)$ & $3.18 \pm 1.31$ (3) & $0.000 *$ \\
\hline Q28 & $1.83 \pm 1.3(1)$ & $2.2 \pm 1.45(1.5)$ & $2.41 \pm 1.52(2)$ & $2.57 \pm 1.5(2)$ & $2.57 \pm 1.54(2)$ & $0.000 *$ \\
\hline Q29 & $3.15 \pm 1.36(3)$ & $3.52 \pm 1.3(4)$ & $3.57 \pm 1.21(4)$ & $3.76 \pm 1.1(4)$ & $3.9 \pm 1.13(4)$ & $0.000^{*}$ \\
\hline Q30 & $3.5 \pm 1.31(4)$ & $3.6 \pm 1.25$ (4) & $3.4 \pm 1.29(4)$ & $3.44 \pm 1.27(4)$ & $3.46 \pm 1.28(4)$ & 0.278 \\
\hline Q31 & $3.42 \pm 1.44(4)$ & $3.62 \pm 1.36(4)$ & $3.6 \pm 1.34(4)$ & $3.56 \pm 1.27(4)$ & $3.74 \pm 1.24(4)$ & 0.214 \\
\hline Q32 & $2.39 \pm 1.23(2)$ & $2.61 \pm 1.39(3)$ & $2.76 \pm 1.28(3)$ & $2.73 \pm 1.24(3)$ & $2.93 \pm 1.31$ & $0.000^{*}$ \\
\hline Q33 & $3.41 \pm 1.32(3)$ & $3.61 \pm 1.26(4)$ & $3.78 \pm 1.22(4)$ & $3.93 \pm 1.16(4)$ & $3.96 \pm 1.1(4)$ & $0.000^{*}$ \\
\hline Q34 & $3.8 \pm 1.28(4)$ & $3.75 \pm 1.19(4)$ & $3.49 \pm 1.27(4)$ & $3.47 \pm 1.24(3)$ & $3.07 \pm 1.19$ (3) & $0.000^{*}$ \\
\hline Q35 & $3.12 \pm 1.08(3)$ & $3.27 \pm 1.13(3)$ & $3.43 \pm 1.07(3)$ & $3.4 \pm 1.1(3)$ & $3.33 \pm 1.14$ (3) & $0.002^{*}$ \\
\hline Q36 & $2.17 \pm 1.17(2)$ & $2.45 \pm 1.21(2)$ & $2.76 \pm 1.21(3)$ & $2.84 \pm 1.18(3)$ & $2.94 \pm 1.21$ (3) & $0.000^{*}$ \\
\hline Q37 & $2.67 \pm 1.19(3)$ & $2.95 \pm 1.28(3)$ & $3.15 \pm 1.19(3)$ & $3.13 \pm 1.18(3)$ & $3.29 \pm 1.26(3)$ & $0.000^{*}$ \\
\hline
\end{tabular}

Istanbul, Turkey; 11.2\%). As an alternative to face-to-face training interrupted by COVID-19, Yuen (20) and Telli (21) reported that many software programs are used in all universities around the world for e-learning, such as Zoom. Mobile learning is a growing trend in dental education, as students prefer smartphones and iPad/computer tablets. The ratio of students connecting to online courses with a cell phone $(31.8 \%)$ was lower than that for connecting with a laptop (47.7\%), although nearly all the students (93.3\%) had (mobile) internet data packages. Mobile learning has also been used to access lessons, as there is no computer or laptop at home. Or it may have shifted from having a single computer as a work or learning environment for more than one person at home to mobile learning. The size of the cell phone is much more convenient for students than laptops, but the screen view is considerably reduced. This may have influenced their preference for computers with better image and sound qualities when participating in online courses. Smartphones and laptops were shown to be popular devices in our study and in a study by Khatoon (7). Another study showed strong interest in using the iPad/tablet for future coursework (22).

While coronavirus affects many areas of life, it has caused universities to complete the current year with distance education. Distance education is generally considered the best solution during the current pandemic; however, the lack of internet and computers is one of the most significant problems faced by students (23). In Turkey, roughly 7.5 million students are studying at the undergraduate level in 207 higher education institutions, with 28,941 students enrolled in dental schools (CoHE Information Management System). According to data from the CoHE, 123 of the 207 universities in Turkey have a Distance Education Application and Research Center. While some universities prepared their programs and started distance education on March 23, others are switching to this education system. There is no single method of distance education for universities at present under these extraordinary conditions. Universities use different methods according to available infrastructure and the number of students; some provide simultaneous distance education while others share the course content they have uploaded to the system. However, these methods cover only theoretical lessons. For courses that require practice, the intention is to offer compensation courses in the summer months after the outbreak ends. (24) As dental education requires intensive clinical practice apart from serious theoretical education, this deficiency is causing inevitable anxiety among students (25). In our study, most dental students (45.9\%, $n=737$ ) expressed the opinion that the distance education model is not an adequate substitute and is not as effective as face-to-face education (59.1\%, $n=949)$. The reason students think is possibly due to their views on dental education, which is comprised of both theoretical and practical components. Jordan et al. (13) likewise reported that interactive, standard didactic education is more effective than asynchronous online education. However, other studies in 
Table 4. Representative comments by students about positive and negative aspects of distance (online) education.

\section{Positive Comments}

I can concentrate much better since

listening to lessons in the home environment is more comfortable than in the classroom.

Negative Comments

My concentration deteriorates when there is a connection problem on the Internet

I don't have to wake up early to attend the courses

Less waste of time and less tired

Thank to the course contents and

Thanks to the course contents and videos uploaded to the system, I can open the lessons and listen again if something is stuck in my mind

I find it very successful to plan and implement the Distance education system in a short time.
When the lessons are explained asynchronous, we cannot ask the sections that we do not understand because we cannot participate actively.

\section{If the lesson duration is} longer than 30 minutes, my concentration deteriorates because I constantly look at the computer screen

\section{Since some trainers} do not have sufficient infrastructure about the system, there may be a waste of time in lecturing.

\section{Only theoretical training} can be done with online training. Our clinical training is incomplete the literature report that dental students have generally positive attitudes toward online learning (26-30). Interpreting these responses as positive feedback would be a natural reaction due to the use of distance education as an emergency solution during the pandemic period. The reason for the difference between the two studies is that dental students require an adequate physical setting and psychomotor skills during their academic years, which cannot be replaced with distance learning, as is currently being conducted during the COVID-19 pandemic (31). Besides, in these studies, the online learning modules were integrated with face-to-face learning, while in the present study, learning was entirely performed via distance learning (i.e., full online). It was previously reported that full online learning leads to a lost sense of reality and learning mostly depends on the dental students' commitment to the courses (32).

Internet difficulties are among the most important problems faced by students thus far in the scope of distance education (33). It has been noted that students' internet quotas are insufficient, as video education requires downloading course materials from time to time. In this process, which became compulsory due to the COVID-19 pandemic, it became crucial to determine whether the infrastructure of each university, the content of the education, the ability of the educators to use this technology, and the students' access to the courses are compatible. Some foundation universities in Turkey have stated that they will contribute hardware or internet access to their students. However, because providing such support for students in public universities with their limited budgets may not be feasible, the perspectives of students in state universities may differ from those studying in private universities. Our findings revealed that dental students at state universities have more negative thoughts about distance education.

Although the technical operation of the system is unproblematic, the necessary interaction required during intensive theoretical lessons may be somewhat restricted. Although most participants $(59.1 \%, n=949)$ in our study reported having the technological infrastructure to carry out distance education courses in their homes, more than half (54\%) expressed that distance education should be done only when in-class education cannot be provided or to support it. In this study, the preference for online learning was influenced by the year of study. Among students who preferred distance online learning, the percentage of senior students was significantly higher than the young students. The highest rate of negative feedback to the question "I think distance education is a good education model" was from first-year students. However, studies conducted by Sritongthaworn et al. (34) and Teo et al. (35) reported that younger students tend to adapt to e-learning. The reason may be that younger students have difficulty following and understanding online lessons because they have not yet acquired enough background knowledge in the field.

This study provides valuable data on undergraduate dental students in Turkey. However, there may be differences among the various schools in the country. Therefore, the authors are developing a country-wide study with more participants to examine differences between online and traditional curricula by assessing both undergraduate students' and educators' opinions to achieve more meaningful results. Given the fact that the pandemic may take longer, it is assumed that Augmented Reality/Virtual Reality technology will play a dominant role in the future development of dental education. An educational model can be developed to cover various teaching interests, including digital dental education, Web-based knowledge transfers and digital surface mapping, dental simulator motor skills including IOS, and specialized technologies such as digital radiography.

In this study, only the perspectives of students regarding online education were evaluated. Comparing students' opinions with those of educators will help fill in the gaps of a thorough evaluation of distance education, as it seems likely to continue in the future. Also, this investigation is limited to 23 dental schools and 1605 dental students, a broader sample including more dental schools with a greater number of dental students is desirable.

\section{Conclusion}

Within the limitations of this study, it can be concluded that distance (online) education is commonly used by dental schools during the pandemic period, and students' attitudes toward the use of distance learning are not positive.

Türkçe Özet: Diş hekimliği öğrencilerinin Covid-19 pandemisi sürecinde çevrimiçi eğitim ile öğrenmeye ilişkin algı durumları Amaç: Bu çalışmanın amacı, dişhekimliği lisans öğrencilerinin uzaktan (çevrimiçi) ögrenmeye yönelik kullanım alışkanlıklarını, tutumlarını ve algılarını değerlendirmek ve bu tutumlarla ilgili değişkenleri belirlemektir. Gereç 
ve Yöntem: Çalışmaya gönüllü olarak katılan 1,605 dişhekimliği lisans öğrencisi dahil edildi. Veri toplama aracı olarak uzaktan öğrenme tutum ölçeği, kişisel bilgilerle ilgili bir anket ve açık uçlu sorulardan oluşturuldu. Dişhekimliği öğrencilerinin devam ettikleri yıllara ve dişhekimliği fakültesinin türüne göre uzaktan eğitime yönelik algıları değerlendirildi. Bulgular: Öğrencilerin çoğu tarafından, dişhekimliği derslerinde uzaktan eğitimin geleneksel yüz yüze eğitim kadar etkili olmadığı ifade edildi. (\% 59.1, $n=949)$. Devlet üniversitelerinde okuyan öğrenciler uzaktan eğitime daha olumsuz bakarken, birinci sınıf öğrencilerinin memnuniyet puanları diğer öğrencilere göre anlamlı derecede düşük bulundu ( $p$ <0.05). Sonuç: Dişhekimliği öğrencileri, COViD-19 pandemisine bağlı olarak geleneksel eğitimin kesintiye uğramasından ve eğitimlerine çevrimiçi olarak devam etmek zorunda kalmaktan genel olarak memnun değillerdi. Ancak, bu koşullar altında çevrimiçi eğitimi, eğitimin tamamen askıya alınmadan devam etmesine imkan sağlayan bir avantaj olarak gördüler. Anahtar Kelimeler: COVID-19, anket, uzaktan eğitim, çevrimiçi eğitim, lisans öğrencisi

Ethics Committee Approval: This project has been reviewed and approved by the Ethical Committee of Bezmialem Vakif University $(06 / 108)$ on May $5,2020$.

Informed Consent: Participants provided informed constent.

Peer-review: Externally peer-reviewed.

Author contributions: ASG participated in designing the study. ASG, YSU, ND participated in generating the data for the study. ASG, YSU participated in gathering the data for the study. ASG, YSU, ND participated in the analysis of the data. ASG wrote the majority of the original draft of the paper. ASG, YSU, ND participated in writing the paper. ASG has had access to all of the raw data of the study. ASG has reviewed the pertinent raw data on which the results and conclusions of this study are based. ASG, YSU, ND have approved the final version of this paper. ASG guarantees that all individuals who meet the Journal's authorship criteria are included as authors of this paper.

Conflict of Interest: The authors declared no conflict of interest.

Financial Disclosure: The autzhors declared that they have received no financial support.

\section{References}

1. McCutcheon LRM, Alzghari SK, Lee YR, Long WG, Marquez R. Interprofessional education and distance education: A review and appraisal of the current literature. Curr Pharm Teach Learn 2017;9:729-36. [CrossRef]

2. Asarbakhsh M, Sandars J. E-learning: the essential usability perspective. Clin Teach 2013;10:47-50. [CrossRef]

3. Mooney GA, Bligh JG. Information technology in medical education: current and future applications. Postgrad Med J 1997;73:701-4. [CrossRef]

4. Mattheos N, Stefanovic N, Apse P, Attstrom R, Buchanan J, Brown $P$, et al. Potential of information technology in dental education. Eur J Dent Educ 2008;12 Suppl 1:85-92.

5. A. Suner YY, B. Piskin. Mobile learning in dentistry: usage habits, attitudes and perceptions of undergraduate students,. PEERJ $2019 ; 7391$.

6. Constantinescu-Dobra A, Maier V. Generation Z and Online Dentistry. An Exploratory Survey on the Romanian Market 2017. p. 291-6.

7. Khatoon B, Hill KB, Walmsley AD. Dental students' uptake of mobile technologies. Br Dent J 2014;216:669-73. [CrossRef]

8. Fraenkel JWN, Hyun $\mathrm{H}$. How to design and evaluate research in education New York: McGraw-Hill Education; 2014.

9. S Deshpande AK, J Chahande. Perceptions of faculty and students regarding use of mobile apps for learning in dentistry: A questionnaire based study Journal of Education Technology in Health Sciences 2016;3:128-30.
10. Rung A, Warnke F, Mattheos N. Investigating the use of smartphones for learning purposes by Australian dental students. JMIR Mhealth Uhealth 2014;2:e20.

11. Çelik A.M-learning attitude scale: validity and reliability analyses. Journal of Research in Education and Teaching 2013;2:172-85.

12. Ni MY, Yang L, Leung CMC, Li N, Yao Xl, Wang Y, et al. Mental Health, Risk Factors, and Social Media Use During the COVID-19 Epidemic and Cordon Sanitaire Among the Community and Health Professionals in Wuhan, China: Cross-Sectional Survey. JMIR Ment Health 2020;7:e19009.

13. Jordan J, Jalali A, Clarke S, Dyne P, Spector T, Coates W. Asynchronous vs didactic education: it's too early to throw in the towel on tradition. BMC Med Educ 2013;13:105. [CrossRef]

14. Halpin PA, Lockwood MKK. The use of Twitter and Zoom videoconferencing in healthcare professions seminar course benefits students at a commuter college. Adv Physiol Educ 2019;43:246-9. [CrossRef]

15. Martin N, Lazalde OM, Stokes C, Romano D. An evaluation of remote communication versus face-to-face in clinical dental education. Br Dent J 2012;212:277-82. [CrossRef]

16. Poblete $P$, Nieto $E$. Does time matter? WhatsApp vs electronic mail for dental education. A pilot study. Eur J Dent Educ 2020;24:121-5. [CrossRef]

17. Das R, Manaktala N, Bhatia T, Agarwal S, Natarajan S, Lewis AJ, et al. Efficiency of Mobile Video Sharing Application (WhatsApp(R)) in Live Field Image Transmission for Telepathology. J Med Syst 2020;44:109. [CrossRef]

18. Spallek H, Turner SP, Donate-Bartfield E, Chambers D, McAndrew M, Zarkowski $P$, et al. Social Media in the Dental School Environment, Part A: Benefits, Challenges, and Recommendations for Use. J Dent Educ 2015;79:1140-52. [CrossRef]

19. Alshiekhly U, Arrar R, Barngkgei I, Dashash M. Facebook as a learning environment for teaching medical emergencies in dental practice. Educ Health (Abingdon) 2015;28:176-80. [CrossRef]

20. Yuen J, Xie F. Medical education during the COVID-19 pandemic: perspectives from UK trainees. Postgrad Med J 2020;96:432-3. [CrossRef]

21. Telli Yamamoto G AD. Coronavirüs ve Çevrimiçi (Online) Eğitimin Önlenemeyen Yükselişi. Journal of University Research 2020;3:25-34.

22. Gosper M, Malfroy J, McKenzie J. Students' experiences and expectations of technologies: An Australian study designed to inform planning and development decisions. Australasian Journal of Educational Technology 2013;29:268-82. [CrossRef]

23. Saeed SG, Bain J, Khoo E, Siqueira WL. COVID-19: Finding silver linings for dental education. J Dent Educ 2020.

24. Machado RA, Bonan PRF, Perez D, Martelli JH. COVID-19 pandemic and the impact on dental education: discussing current and future perspectives. Braz Oral Res 2020;34:e083.

25. Deery C. The COVID-19 pandemic: implications for dental education. Evid Based Dent 2020;21:46-7. [CrossRef]

26. Bains M, Reynolds PA, McDonald F, Sherriff M. Effectiveness and acceptability of face-to-face, blended and e-learning: a randomised trial of orthodontic undergraduates. Eur J Dent Educ 2011;15:110-7. [CrossRef]

27. Brumini G, Spalj S, Mavrinac M, Biocina-Lukenda D, Strujic $M$, Brumini M. Attitudes towards e-learning amongst dental students at the universities in Croatia. Eur J Dent Educ 2014;18:15-23. [CrossRef]

28. Ramlogan S, Raman V, Sweet J. A comparison of two forms of teaching instruction: video vs. live lecture for education in clinical periodontology. Eur J Dent Educ 2014;18:31-8. [CrossRef]

29. Schlenz MA, Schmidt A, Wostmann B, Kramer N, Schulz-Weidner $\mathrm{N}$. Students' and lecturers' perspective on the implementation of online learning in dental education due to SARS-CoV-2 (COVID-19): a cross-sectional study. BMC Med Educ 2020;20:354. [CrossRef] 
30. Wang K, Zhang L, Ye L. A nationwide survey of online teaching strategies in dental education in China. J Dent Educ 2021;85:12834. [CrossRef]

31. Quinn B, Field J, Gorter R, Akota I, Manzanares MC, Paganelli C, et al. COVID-19: The immediate response of european academic dental institutions and future implications for dental education. Eur J Dent Educ 2020;24:811-4. [CrossRef]

32. Lo H-C. Utilizing Computer-mediated Communication Tools for Problem-based Learning. Educational Technology \& Society 2009;12:205-13.

33. Pontual MLA, do Nascimento EHL, da Cruz Perez DE, Pontual AA, Ramos-Perez FM. Challenges in oral radiology teaching during
COVID-19 pandemic. Dentomaxillofac Radiol 2020;49:20200178. [CrossRef]

34. Siritongthaworn S, Krairit D, Dimmitt N, Paul H. The study of e-learning technology implementation: A preliminary investigation of universities in Thailand. Education and Information Technologies 2006;11:137-60. [CrossRef]

35. Teo T, Luan W, Thammetar T, Chattiwat W. Assessing e-learning acceptance by university students in Thailand. Australasian Journal of Educational Technology 2011;27:1356-68. [CrossRef] 